\title{
Prostate Cancer Screening in Men of African Descent: 15-year Results of the Tobago Prostate Cancer Survey
}

\author{
AL Patrick ${ }^{1,2}$, JB Nelson ${ }^{3,4}$, JL Weissfeld ${ }^{2,4}$, R Dhir ${ }^{4,5}$, RJ Phillips ${ }^{2}$, JM Zmuda ${ }^{2,4}$, CH Bunker ${ }^{2,4}$
}

\begin{abstract}
Objective: To compare all-cause-mortality in screening-detected prostate cancer cases versus non-cases after a median 12.2-year follow-up.

Methods: In this prospective, population-based study of 3089 Afro-Caribbean men aged 40-79 years in Tobago, Trinidad and Tobago, West Indies, all men were screened for prostate cancer (serum prostate specific antigen and/or digital rectal exam) one to three times between 1997 and 2007 and followed for mortality to 2012. Among 502 men diagnosed with prostate cancer, 81 younger men underwent radical retropubic prostatectomy. Minimal treatment was available for older men. Survival curves compared all-cause-mortality in cases versus non-cases within 10-year age groups at first screening.

Results: There were 350 all-cause-deaths over 34089 person-years of follow-up. All-causesurvival curves in men aged 60 years or above at first screening did not diverge between cases and non-cases until after 10-12 years of follow-up ( $\mathrm{p}>0.36$ ). In contrast, among men first screened at age 50-59 years, survival was lower in cases, with survival curves diverging at seven years $(\mathrm{p}=0.003)$. Survival in men aged 50-59 years who underwent prostatectomy was similar to survival in non-cases $(\mathrm{p}=0.63)$.

Conclusion: Among men aged 60 years or above, the absence of excess all-cause-mortality among screening-detected prostate cancer cases provides argument against the utility of routine prostate cancer screening in this older population of African descent. However, the significantly poorer survival in men aged 50-59 years with screening-detected prostate cancer, compared with screened men without prostate cancer, along with the potential for prostate cancer treatment to improve survival, supports the continuation of prostate cancer screening in this age group, pending further research to assess the risks and benefits.
\end{abstract}

Keywords: Afro-Caribbean, mortality, prostate cancer, prostatectomy, screening

From: ${ }^{1}$ Tobago Health Studies Office, Scarborough, Tobago, Trinidad and Tobago, West Indies, ${ }^{2}$ Department of Epidemiology, University of Pittsburgh, Pittsburgh, Pennsylvania, United States of America, ${ }^{3}$ Department of Urology, University of Pittsburgh, Pittsburgh, Pennsylvania, United States of America, ${ }^{4}$ University of Pittsburgh Cancer Institute, Pittsburgh, Pennsylvania, United States of America and ${ }^{5}$ Department of Pathology, University of Pittsburgh, Pittsburgh, Pennsylvania, United States of America.

Correspondence: Dr CH Bunker, Department of Epidemiology, A542 Crabtree Hall, 130 DeSoto Street, Pittsburgh, PA 15261, United States of America. Email: bunkerc@pitt.edu 


\title{
Tamización del cáncer de próstata en hombres de ascendencia africana: resultados de 15 años de la Encuesta de Cáncer de Próstata de Tobago
}

\author{
AL Patrick ${ }^{1,2}$, JB Nelson ${ }^{3,4}$, JL Weissfeld ${ }^{2,4}$, R Dhir ${ }^{4,5}$, RJ Phillips², JM Zmuda ${ }^{2,4}$, CH Bunker ${ }^{2,4}$
}

\section{RESUMEN}

Objetivo: Comparar la mortalidad por todas las causas en casos de cáncer de próstata frente a no casos tras un seguimiento medio de 12.2 años.

Métodos: En este estudio prospectivo poblacional de 3089 hombres afrocaribeños de 40-79 años en Tobago, Trinidad y Tobago, West Indies, todos los hombres fueron expuestos a tamizaje de cáncer de próstata (antígeno prostático especifico en suero y/o examen rectal digital) de una a tres veces entre 1997 y 2007, y a un seguimiento de la mortalidad hasta 2012. De entre los 502 hombres diagnosticados con cáncer de próstata, a 81 hombres de los más jóvenes se les practicó una prostatectomía retropúbica radical. El tratamiento mínimo estuvo disponible para los hombres mayores. Las curvas de supervivencia compararon la mortalidad por todas las causas en los casos frente a los no casos dentro de los grupos de edades de 10 años en la primera tamización.

Resultados: Hubo 350 muertes por todas las causas con más de 34089 persona-años de seguimiento. Las curvas de supervivencia por todas las causas en hombres de 60 años o más en el primer tamizaje, no divergieron entre casos y no casos hasta después de 10 a 12 años de seguimiento ( $\mathrm{p}>0.36)$. En cambio, entre los hombres tamizados por primera vez a la edad 50-59 años, la supervivencia fue menor en los casos, con curvas de supervivencia divergentes a los siete años ( $\mathrm{p}=0.003)$. La supervivencia en los hombres de 50-59 años que tuvieron prostatectomía fue similar a la supervivencia en los no casos $(\mathrm{p}=0.63)$.

Conclusión: Entre los hombres de 60 años o más, la ausencia de exceso de mortalidad por todas las causas entre los casos de cáncer de próstata detectados por tamizaje proporciona argumentos contra la utilidad de la tamización rutinaria del cáncer de próstata en esta población mayor de ascendencia africana. Sin embargo, la supervivencia significativamente más pobre en hombres de 50 a 59 años con cáncer de próstata detectado mediante tamizaje - en comparación con los hombres tamizados sin cáncer de próstata, además de las posibilidades de tratamiento del cáncer de próstata para mejorar la supervivencia - respalda la continuación del tamizaje del cáncer de próstata en este grupo etario, quedando pendiente una investigación ulterior a fin de evaluar sus riesgos y beneficios.

Palabras clave: Afrocaribeño, mortalidad, cáncer de próstata, prostatectomía, tamizaje

West Indian Med J 2018; 67 (4): 335

\section{INTRODUCTION}

African-American men and other populations of African descent experience a considerably higher burden of prostate cancer incidence, prevalence and mortality than Caucasians $(1,2)$. In recent years, there has been growing concern that prostate cancer screening leads to 'overdiagnosis' of prostate cancer with the attendant stress of living with a cancer diagnosis, and exposure to treatments which often diminish the quality of life but without overall benefits in long-term survival (3).
This concern underlaid the US Preventive Services Task Force's (USPSTF) 2012 blanket recommendation against routine prostate cancer screening (3). However, this recommendation was based primarily on large clinical trials $(4,5)$, which were not powered to address the effect of screening on mortality in high-risk subgroups such as men of African descent. In the absence of adequate randomized clinical trial data for men of African descent, evidence from observational trials must be used. This paper reports on all-cause-mortality after 15 years 
of follow-up of prostate cancer screening in a large, population-based cohort of Afro-Caribbean men. We hypothesized that all-cause-mortality would be higher in screened men diagnosed compared with those not diagnosed with prostate cancer.

\section{SUBJECTS AND METHODS}

The Tobago Prostate Cancer Survey is a prospective, population-based study of prostate cancer screening conducted on the island of Tobago, Trinidad and Tobago, West Indies, since 1997 (2). An earlier health needs assessment for the island of Tobago noted high prostate cancer mortality for men aged 65 years or above (6). This study was designed to determine the risk and potential risk factors for prostate cancer in Tobago men aged 40 years or above. The analysis assembled evidence to address the question of whether men of African descent should be screened for prostate cancer.
We screened 3089 men aged $40-79$ years (38\% of the male population in this age group (7)) for prostate cancer. Prostate cancer screening in this population was rare prior to this study. Men with a serum prostate specific antigen (PSA) of $\geq 4 \mathrm{ng} / \mathrm{ml}$ (University of Pittsburgh Medical Center Clinical Laboratory) or an abnormal digital rectal exam were offered a sextant, ultrasound-guided biopsy (prostate cancer diagnosis at the University of Pittsburgh Urological Pathology Laboratory). Men were screened one to three times (Fig. 1): baseline, 1997-2002 (342/3089 screeningdetected prevalent cases; Table 1); Visit 2, 2000-02 (69/1466 screening-detected incident cases; Table 2); and Visit 3, 2004-07 (91/1632 screening-detected incident cases; Table 3 ).

The study protocol and consent forms were approved by the institutional review boards of Tobago's Division of Health and Social Services and the University of

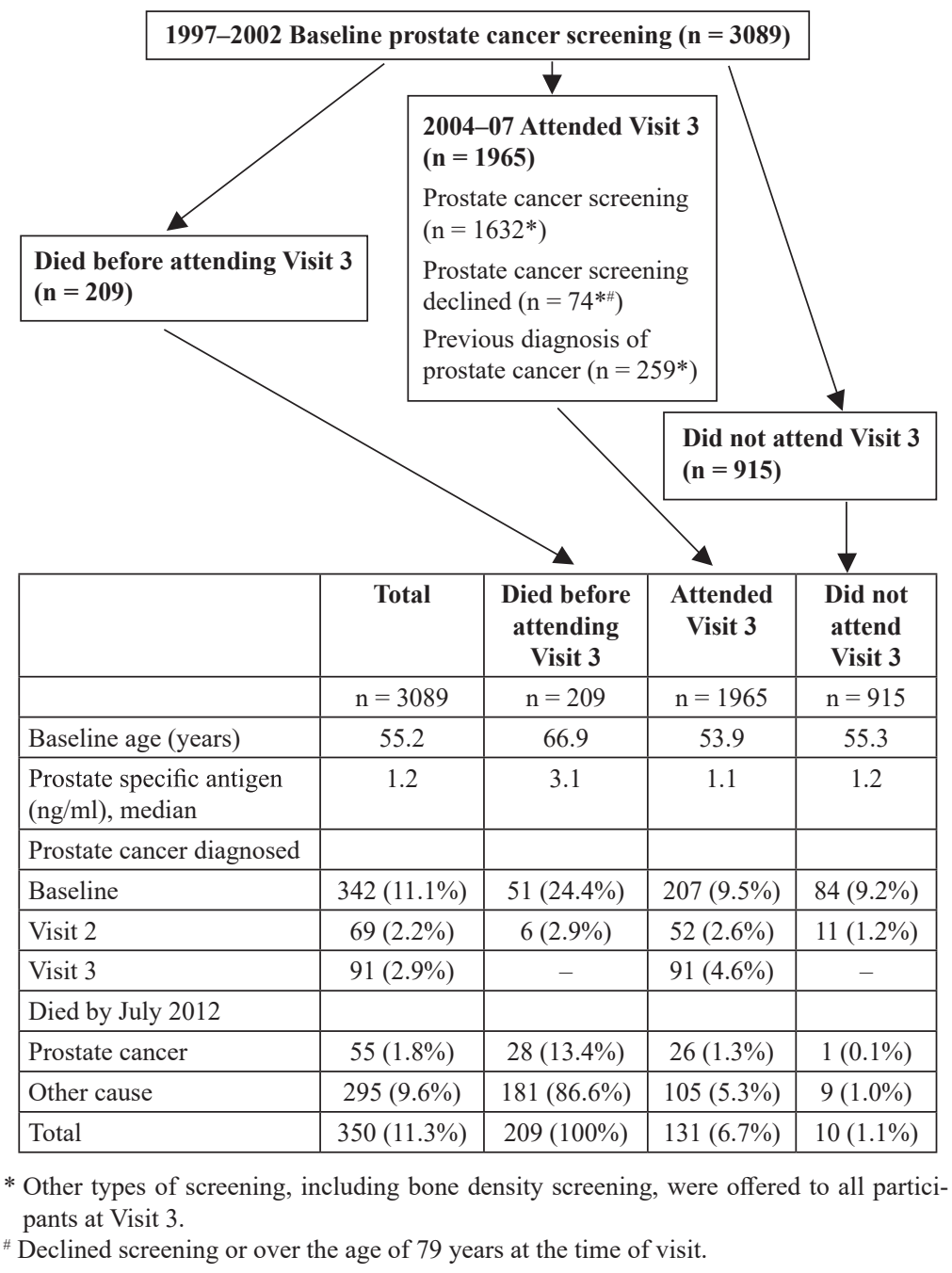

Fig. 1: Tobago Prostate Cancer Survey - study diagram. 
Table 1: Screening-detected prostate cancer prevalence at the baseline visit, 1997-2002

\begin{tabular}{|c|c|c|c|c|c|c|c|c|c|c|}
\hline $\begin{array}{l}\text { Age group } \\
\text { at baseline } \\
\text { (years) }\end{array}$ & $\begin{array}{c}\text { Tobago } \\
\text { male } \\
\text { population* }\end{array}$ & Screened & $\begin{array}{c}\text { Population } \\
\text { screened } \\
(\%)\end{array}$ & $\begin{array}{c}\text { Abnormal } \\
\text { screening** }\end{array}$ & $\begin{array}{c}\text { Abnormal } \\
(\%)\end{array}$ & Biopsied & $\begin{array}{c}\text { Abnormal } \\
\text { biopsied } \\
(\%)\end{array}$ & $\begin{array}{c}\text { Prostate } \\
\text { cancer } \\
\text { diagnosed }\end{array}$ & $\begin{array}{c}\text { Biopsied } \\
\text { diagnosed } \\
(\%)\end{array}$ & $\begin{array}{c}\text { Screened } \\
\text { diagnosed } \\
(\%) \\
\end{array}$ \\
\hline $40-44$ & 1911 & 608 & 31.8 & 45 & 7.4 & 37 & 82.2 & 2 & 5.4 & 0.3 \\
\hline $45-49$ & 1495 & 534 & 35.7 & 68 & 12.7 & 63 & 92.6 & 12 & 19.0 & 2.2 \\
\hline $50-54$ & 1255 & 464 & 37.0 & 113 & 24.4 & 102 & 90.3 & 29 & 28.4 & 6.3 \\
\hline $55-59$ & 933 & 401 & 43.0 & 138 & 34.4 & 119 & 86.2 & 43 & 36.1 & 10.7 \\
\hline $60-64$ & 877 & 383 & 43.7 & 157 & 41.0 & 135 & 86.0 & 65 & 48.1 & 17.0 \\
\hline $65-69$ & 681 & 317 & 46.5 & 175 & 55.2 & 155 & 88.6 & 80 & 51.6 & 25.2 \\
\hline $70-74$ & 557 & 237 & 42.5 & 145 & 61.2 & 117 & 80.7 & 59 & 50.4 & 24.9 \\
\hline $75-79$ & 369 & 145 & 39.3 & 111 & 76.6 & 86 & 77.5 & 52 & 60.5 & 35.9 \\
\hline Total & 8078 & 3089 & 38.2 & 952 & 30.8 & 814 & 85.5 & 342 & 42.0 & 11.1 \\
\hline
\end{tabular}

* Caribbean Community Secretariat (7).

** Serum prostate specific antigen of $\geq 4 \mathrm{ng} / \mathrm{ml}$ and/or digital rectal exam suspicious for prostate cancer.

Table 2: Screening-detected prostate cancer incidence at Visit 2, 2000-02

\begin{tabular}{|c|c|c|c|c|c|c|c|c|c|c|}
\hline $\begin{array}{l}\text { Age group } \\
\text { at Visit } 2 \\
\text { (years) }\end{array}$ & $\begin{array}{c}\text { Screened at } \\
\text { baseline* }\end{array}$ & $\begin{array}{l}\text { Screened at } \\
\text { Visit 2*** }\end{array}$ & $\begin{array}{c}\text { Rescreened } \\
(\%)\end{array}$ & $\begin{array}{l}\text { Abnormal } \\
\text { screen *** }\end{array}$ & $\begin{array}{c}\text { Abnormal } \\
(\%)\end{array}$ & Biopsied & $\begin{array}{c}\text { Abnormal } \\
\text { biopsied } \\
(\%)\end{array}$ & $\begin{array}{c}\text { Prostate } \\
\text { cancer } \\
\text { diagnosed }\end{array}$ & $\begin{array}{c}\text { Biopsied } \\
\text { diagnosed } \\
(\%)\end{array}$ & $\begin{array}{c}\text { Screened } \\
\text { diagnosed } \\
(\%)\end{array}$ \\
\hline $40-44$ & 470 & 179 & 38.1 & 6 & 3.4 & 4 & 66.7 & 0 & 0.0 & 0.0 \\
\hline $45-49$ & 507 & 268 & 52.9 & 26 & 9.7 & 22 & 84.6 & 4 & 18.2 & 1.5 \\
\hline $50-54$ & 489 & 272 & 55.6 & 24 & 8.8 & 21 & 87.5 & 4 & 19.0 & 1.5 \\
\hline $55-59$ & 342 & 188 & 55.0 & 44 & 23.4 & 37 & 84.1 & 13 & 35.1 & 6.9 \\
\hline $60-64$ & 328 & 196 & 59.8 & 45 & 23.0 & 33 & 73.3 & 9 & 27.3 & 4.6 \\
\hline $65-69$ & 270 & 162 & 60.0 & 64 & 39.5 & 46 & 71.9 & 17 & 37.0 & 10.5 \\
\hline $70-74$ & 199 & 124 & 62.3 & 56 & 45.2 & 45 & 80.4 & 12 & 26.7 & 9.7 \\
\hline $75-79$ & 112 & 58 & 51.8 & 29 & 50.0 & 18 & 62.1 & 8 & 44.4 & 13.8 \\
\hline $80-84$ & 30 & 19 & 63.3 & 11 & 57.9 & 5 & 45.5 & 2 & 40.0 & 10.5 \\
\hline Total & 2747 & 1466 & 53.4 & 305 & 20.8 & 231 & 75.7 & 69 & 29.9 & 4.7 \\
\hline
\end{tabular}

* Excludes 342 men diagnosed with prostate cancer at baseline visit.

** Visit 2 was truncated by a funding hiatus.

*** Serum prostate specific antigen of $\geq 4 \mathrm{ng} / \mathrm{ml}$ and/or digital rectal exam suspicious for prostate cancer.

Table 3: Screening-detected prostate cancer incidence at Visit 3, 2004-07

\begin{tabular}{|c|c|c|c|c|c|c|c|c|c|c|}
\hline $\begin{array}{l}\text { Age group } \\
\text { at Visit } 3 \\
\text { (years) }\end{array}$ & $\begin{array}{c}\text { Screened } \\
\text { base at } \\
\text { baseline* }\end{array}$ & $\begin{array}{c}\text { Screened at } \\
\text { Visit } 3 * *\end{array}$ & $\begin{array}{c}\text { Rescreened } \\
(\%)\end{array}$ & $\begin{array}{c}\text { Abnormal } \\
\text { Screening*** }\end{array}$ & $\begin{array}{c}\text { Abnormal } \\
(\%)\end{array}$ & Biopsied & $\begin{array}{c}\text { Abnormal } \\
\text { biopsied } \\
(\%)\end{array}$ & $\begin{array}{c}\text { Prostate } \\
\text { cancer } \\
\text { diagnosed }\end{array}$ & $\begin{array}{c}\text { Biopsied } \\
\text { diagnosed } \\
(\%)\end{array}$ & $\begin{array}{c}\text { Screened } \\
\text { diagnosed } \\
(\%)\end{array}$ \\
\hline $40-44$ & 50 & 29 & 58.0 & 3 & 10.3 & 3 & 100.0 & 0 & 0 & 0 \\
\hline $45-49$ & 520 & 343 & 66.0 & 35 & 10.2 & 33 & 94.3 & 8 & 24.2 & 2.3 \\
\hline $50-54$ & 492 & 347 & 70.5 & 45 & 13.0 & 44 & 97.8 & 11 & 25.0 & 3.2 \\
\hline $55-59$ & 445 & 282 & 63.4 & 57 & 20.2 & 56 & 98.2 & 13 & 23.2 & 4.6 \\
\hline $60-64$ & 321 & 235 & 73.2 & 62 & 26.4 & 53 & 85.5 & 17 & 32.1 & 7.2 \\
\hline $65-69$ & 272 & 182 & 66.9 & 66 & 36.3 & 56 & 84.8 & 23 & 41.1 & 12.6 \\
\hline $70-74$ & 206 & 121 & 58.7 & 61 & 50.4 & 44 & 72.1 & 12 & 27.3 & 9.9 \\
\hline $75-79$ & 130 & 68 & 52.3 & 38 & 55.9 & 18 & 47.4 & 6 & 33.3 & 8.8 \\
\hline $80-84$ & 61 & 24 & 39.3 & 13 & 54.2 & 1 & 7.7 & 1 & 100.0 & 4.2 \\
\hline $85-89$ & 8 & 1 & 12.5 & 0 & 0.0 & & & & & \\
\hline Total & 2505 & 1632 & 65.1 & 380 & 23.3 & 308 & 81.1 & 91 & 29.5 & 5.6 \\
\hline
\end{tabular}

* Of 3089 screened at baseline, 411 men who were diagnosed prostate cancer either at baseline or Visit 2 and 173 men who were not previously diagnosed but died before participating in Visit 3 were excluded.

** Men aged 80 years or above at time of visit were not encouraged to participate in Visit 3, but were allowed to participate if they requested.

*** Serum prostate specific antigen of $\geq 4 \mathrm{ng} / \mathrm{ml}$ and/or digital rectal exam suspicious for prostate cancer. 
Pittsburgh. Written informed consent was obtained from each participant.

The availability of androgen ablation medication was sporadic in this population until recent years. Beginning in 2000, volunteer surgical teams from the Department of Urology, University of Pittsburgh, visited Tobago periodically to perform radical retropubic prostatectomies in partnership with the Tobago Regional Hospital. Eighty-one men underwent surgery in 2000-10. Usual criteria for surgery were: age below 60 years (extended to 65 years as the programme gained experience), blood pressure and blood glucose under control, normal electrocardiogram, PSA of $<10 \mathrm{ng} / \mathrm{ml}$, Gleason score of $<8$, and normal nuclear bone scan.

A cumulative file of reported deaths was maintained by study staff based on efforts to contact men for follow-up visits for prostate cancer screening (through 2007) and visits for other types of sub-studies in this cohort (through July 2012), and also through surveillance of newspaper obituaries, church announcements and word of mouth. Of the 387 men reported to have died, death certificates were abstracted for 350 men in July 2012. Certificates not abstracted (37/387 or $9.6 \%$ ) may have been present but not located, the death may have occurred out of the country or the report of death may have been in error. Mortality analyses in this report were based on men for whom death certificates had been abstracted. Men for whom death certificates had not been located were considered to be living.

\section{Data analysis}

Crude age-specific rates of abnormal screening, biopsy and screening-detected prevalent prostate cancer were calculated based on five-year age groups at the baseline visit, age at Visit 2 and age at Visit 3, respectively.

The cause of death was adjudicated by two co-authors from death certificates only. Sixty-five death certificates mentioned prostate cancer. Non-concordant adjudication, which occurred for four death certificates, was resolved by discussion and consensus. Final categorization $(n=55)$ for estimation of prostate cancer-specific mortality combined the categories: underlying $(n=53)$ and probably underlying $(\mathrm{n}=2)$. Possibly underlying $(n=3)$ and probably not underlying $(n=7)$ were included in the category of other cause of death $(n=295)$.

The age-specific prostate cancer mortality rate was calculated as the number of prostate cancer deaths in each five-year age group based on age at death divided by the number of person-years of observation attributed to each five-year age group of follow-up, respectively.
Standardized mortality ratios were calculated based on age-specific prostate cancer mortality rates in US Black and White men in the database of the Surveillance, Epidemiology, and End Results (SEER) Program of the National Cancer Institute, United States of America (USA) (1). Tobago prostate cancer mortality rates were compared with those in US Black and White men in the SEER database (1) and in Barbados men (8), by fiveyear age groups.

All-cause-mortality rates, categorized by five-year age groups at first prostate cancer screening, were calculated based on person-years of follow-up for each man based on his age at first prostate cancer screening to the date of death, or, if still living, to July 1, 2012. All 3089 men screened at baseline were included in the mortality analyses. All-cause-survival curves for men with $(n=502)$ and without $(n=2587)$ prostate cancer at any screening visit were calculated by age group at first screening using life table analysis. Men aged 50-59 years with prostate cancer diagnosis were further subdivided into those who underwent radical retropubic prostatectomy $(\mathrm{n}=44)$ and those who did not $(\mathrm{n}=80)$. Comparisons across groups were based on the Wilcoxon statistic, with pairwise (exact) comparisons among groups. Two-sided statistical significance was set at $p<0.05$. Statistical analyses were performed using IBM SPSS 19.0.

\section{RESULTS}

Table 1 presents the rates of abnormal screening, biopsy and prostate cancer diagnosis in the cohort at baseline. About $11 \%$ of men (342/3089) were diagnosed at baseline, with rates ranging from $2 / 608(0.3 \%)$ in men aged $40-44$ years to $52 / 145(35.9 \%)$ in men aged $75-79$ years. Gleason scores 5, 6, 7, 8, 9 and 10 were recorded for $1 \%, 51 \%, 35 \%, 6 \%, 6 \%$ and $0 \%$ of prevalent cases, respectively.

At Visit 2, 69 of 1466 (4.7\%) screened men were diagnosed with screening-detected incident prostate cancer. Rates ranged from $0 / 179(0 \%)$ among men aged 40-44 years to $8 / 58(13.8 \%)$ among those aged 75-79 years (Table 2). At Visit 3, 91 of 1632 (5.6\%) screened men were diagnosed with screening-detected incident prostate cancer. Rates ranged from 8/343 (2.3\%) among those aged 45-49 years to 6/68 (8.8\%) among men aged 75-79 years (Table 3). As expected, the distribution of Gleason scores 6, 7, 8 and 9 was somewhat lower in incident cases with $59 \%, 35 \%, 4 \%$ and $1 \%$ at Visit 2 and $35 \%, 57 \%, 3 \%$ and $4 \%$ at Visit 3. Of the 3089 men at baseline, 2880 were thought to be alive at Visit 


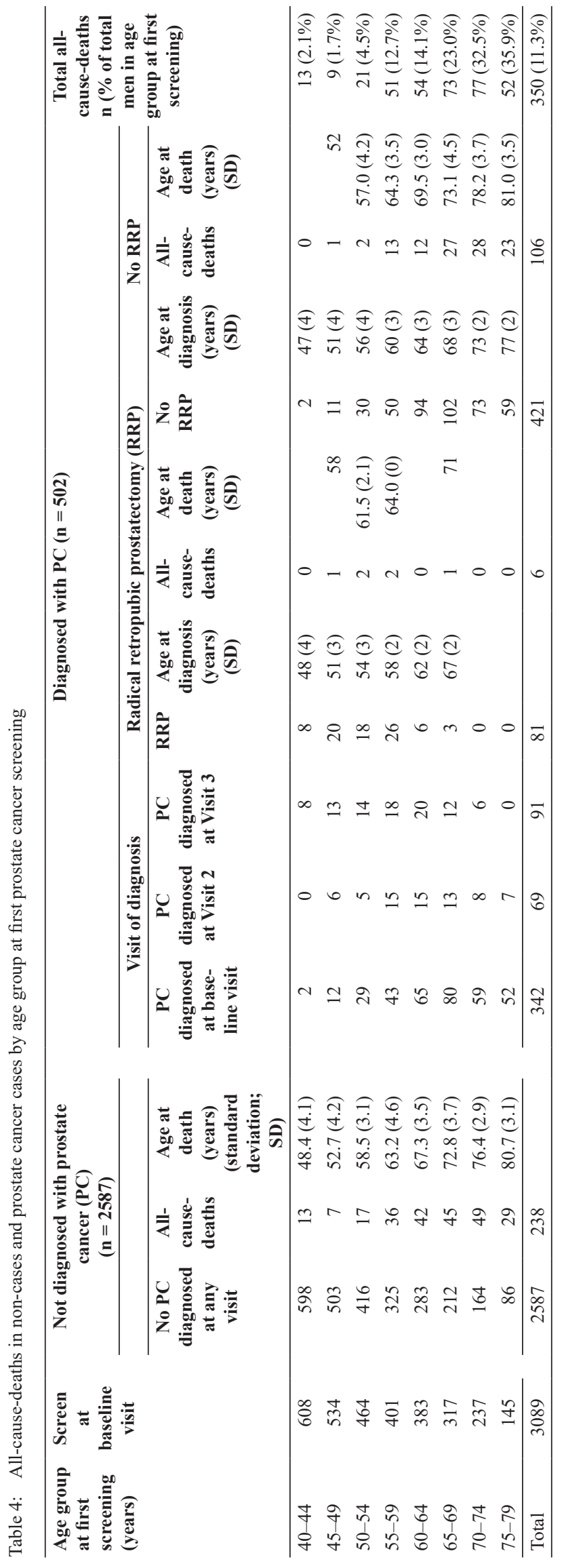


3. Of these, 915/2880 (31.8\%) did not return for Visit 3 (Fig. 1). Men who returned were very similar to the men who did not return with regard to baseline age and median PSA.

Radical retropubic prostatectomy was performed on 81 men. There was no perioperative mortality. Six men died three to nine years post-surgery: three were attributed to prostate cancer and three to other causes (Table 4). Markers of prostate cancer severity were modestly higher among men who did not undergo surgery compared with men who did (data not shown).

Of the death certificates located and abstracted for 350 men (Table 5), 112 were among the 502 diagnosed with prostate cancer; prostate cancer was the underlying or probable underlying cause for $42(37.5 \%)$ of these death certificates. Among 2587 men who had not been screening-diagnosed with prostate cancer, $13(5.5 \%)$ of the 238 death certificates were adjudicated as prostate cancer as the underlying or probable underlying cause. The mean age at baseline for the 112 men with screening-diagnosed prostate cancer was 68.0 (standard deviation (SD): 7.5 ) years and that for the 238 men without screening-diagnosed prostate cancer was 64.4 (SD: 9.5) years.

Age-specific prostate cancer mortality rates ranged from 82.7/100 000 in men aged 60-64 years at death to 1072/100 000 in men aged 80-84 years at death (Table 5, Fig. 2). The standardized mortality ratio was $1.3(95 \%$ confidence interval (CI): 1.1, 1.7) compared with US prostate cancer mortality data for African-Americans, and 3.4 (95\% CI: 2.5, 4.3) compared with US whites (1).
The prostate cancer mortality rate among Tobago men was very similar to the rate observed among Barbados men (8) (Fig. 2).

The maximum follow-up time was 14.8 years from first screening, and the median follow-up time was 12.2 years. There were 350 all-cause-deaths over 34089 person-years of follow-up: 112 deaths over 5337 personyears in 502 cases and 238 over 28752 person-years in 2587 non-cases. Figure 3 shows the survival curves for all-cause-deaths by age group at first screening, comparing men with screening-diagnosed prostate cancer with

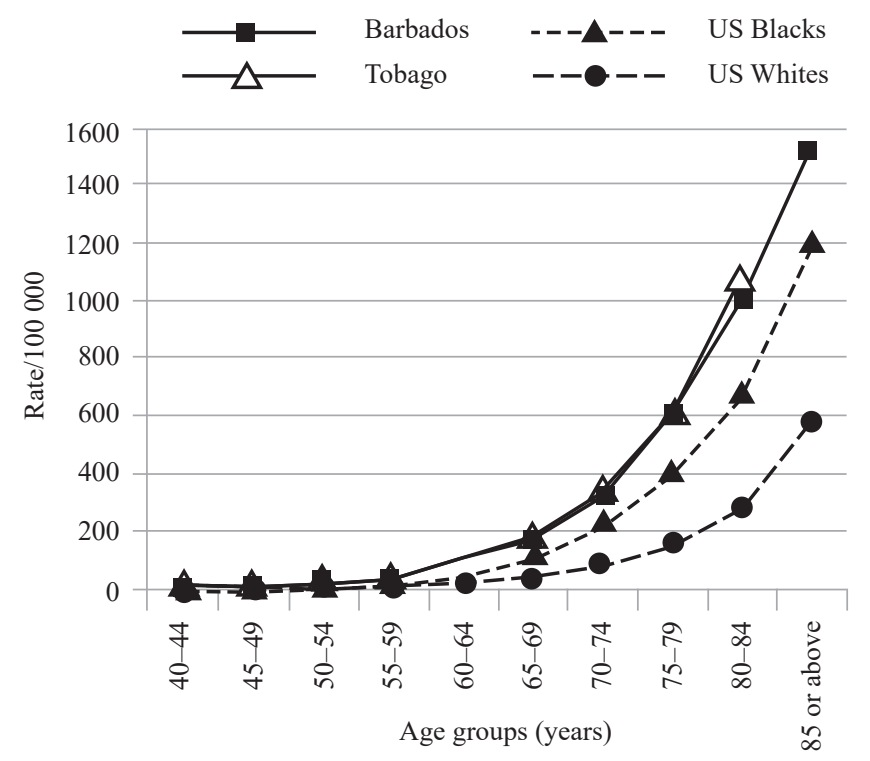

Fig. 2: Age-specific prostate cancer mortality in Tobago (1997-2012), Barbados (1995-2008) (8), US blacks and US whites (2000-10) (1).

Table 5: Age-specific all cause and prostate cancer mortality rates in Tobago men compared with African Americans and non-Hispanic Whites in the database of the Surveillance, Epidemiology, and End Results (SEER) Program of the National Cancer Institute, United States of America

\begin{tabular}{|c|c|c|c|c|c|c|c|}
\hline $\begin{array}{l}\text { Age groups } \\
\text { (years) }\end{array}$ & $\begin{array}{l}\text { Person-years } \\
\text { follow-up }\end{array}$ & $\begin{array}{c}\text { Tobago } \\
\text { all-cause-deaths }\end{array}$ & $\begin{array}{c}\text { Tobago all-cause- } \\
\text { deaths (rate per } \\
100000)\end{array}$ & $\begin{array}{l}\text { Tobago prostate } \\
\text { cancer deaths }\end{array}$ & $\begin{array}{c}\text { Prostate cancer } \\
\text { mortality, } \\
\text { Tobago Blacks*, } \\
\text { 1997-2012 (rate } \\
\text { per } 100 \text { 000) } \\
\end{array}$ & $\begin{array}{c}\text { Prostate cancer } \\
\text { mortality, SEER } \\
\text { US (1) Blacks } \\
2000-10 \text { (rate per } \\
100000 \text { ) } \\
\end{array}$ & $\begin{array}{c}\text { Prostate cancer } \\
\text { mortality, SEER } \\
\text { US (1) non-Hispan- } \\
\text { ic Whites } 2000-10 \\
\text { (rate per } 100000)\end{array}$ \\
\hline $40-44$ & 1577 & 4 & 253.6 & & & 0.52 & 0.16 \\
\hline $45-49$ & 4393 & 4 & 91.1 & & & 2.40 & 0.74 \\
\hline $50-54$ & 5992 & 14 & 233.6 & 1 & & 8.7 & 2.7 \\
\hline $55-59$ & 5380 & 22 & 408.9 & 0 & & 24.0 & 7.6 \\
\hline $60-64$ & 4834 & 39 & 806.8 & 4 & 82.7 & 58.1 & 19.0 \\
\hline 65-69 & 4182 & 59 & 1410.8 & 7 & 167.4 & 118.5 & 40.7 \\
\hline $70-74$ & 3476 & 67 & 1927.5 & 12 & 345.2 & 232.0 & 81.3 \\
\hline $75-79$ & 2520 & 93 & 3690.5 & 15 & 595.2 & 397.5 & 153.6 \\
\hline $80-84$ & 1306 & 38 & 2909.6 & 14 & 1072.0 & 677.2 & 278.7 \\
\hline $85+$ & 429 & 10 & 2331.0 & 2 & & 1200.4 & 580.1 \\
\hline Total & 34089 & 350 & & 55 & & & \\
\hline
\end{tabular}

* Age groups with fewer than four events omitted. 
screened men not diagnosed with prostate cancer. After 14.8 years of follow-up, survival curves did not differ in the age group of $40-49$ years $(p=0.26$; Fig. $3 \mathrm{~A})$. There were only 22 deaths in this age group. However, among men aged 50-59 years at first screening, there was significantly worse survival among men with prostate cancer $(p=0.003$; Fig. 3B). The increased mortality trend started after only seven years of follow-up when these men would have generally been around the age of 60 years. Among older men, there were no significant differences in survival rates between men diagnosed with prostate cancer and those not diagnosed with prostate cancer: age $60-69$ years $(p=0.80)$ and age $70-79$ years $(p=0.36)$. Divergence of survival rates was not observed until after 12 years of follow-up in men aged 60-69 years (Fig. 3C) and after 10 years in men aged $70-79$ years (Fig. 3D). In the age group of 50-59 years, survival in those with no surgery was significantly lower than survival in men not diagnosed with prostate cancer $(p=0.001)$. In contrast, men who underwent radical prostatectomy experienced the same survival over 15 years of follow-up as those not diagnosed with prostate cancer (Fig. 4B).

\section{DISCUSSION}

We compared all-cause-mortality among men of African ancestry with and without screening-diagnosed prostate cancer. Our most important finding was that contrary to our expectation, men first screened over the age of 60 years who were diagnosed with prostate cancer and followed up for a maximum of 14.8 years did not die
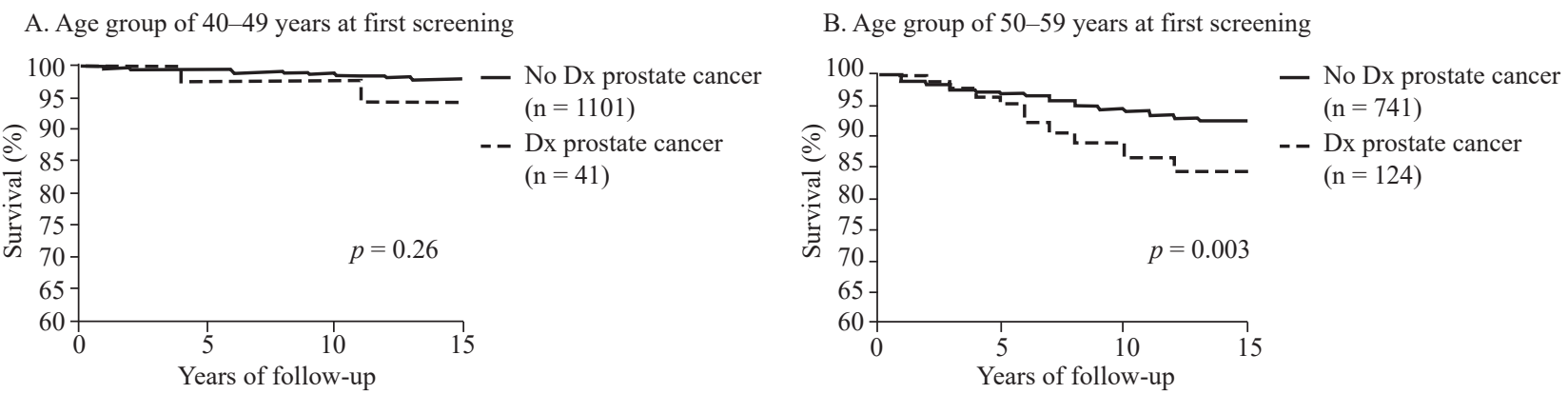

C. Age group of 60-69 years at first screening

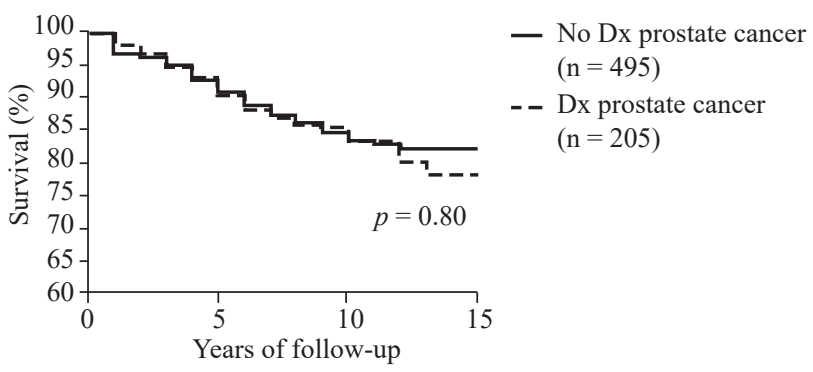

D. Age group of $70-79$ years at first screening

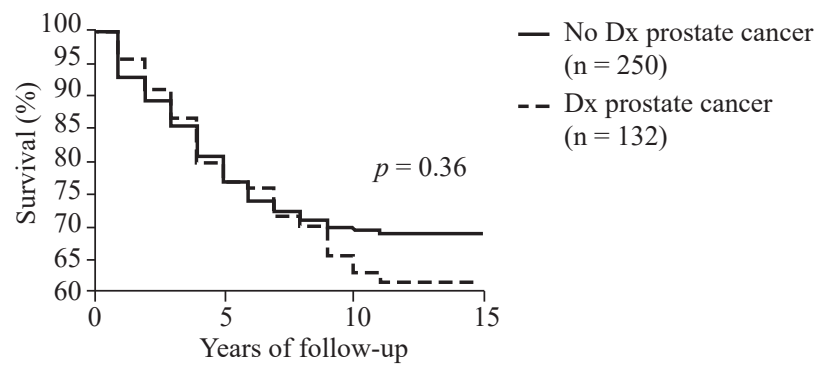

Fig. 3: Cumulative survival curves comparing men without screening-diagnosis of prostate cancer (No Dx prostate cancer) to men with screening-diagnosis of prostate cancer at any visit (Dx prostate cancer), Tobago, 1997-2012, by 10-year age groups at first screening.

A. Age group of $40-49$ years at first screening

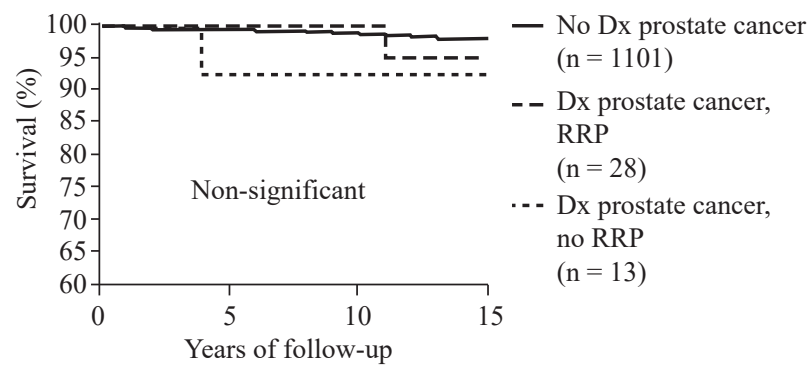

B. Age group of 50-59 years at first screening

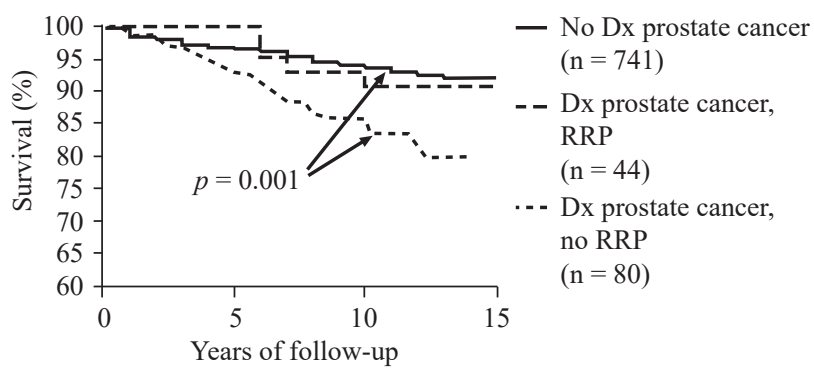

Fig. 4: Cumulative survival curves comparing men without screening-diagnosis of prostate cancer (No Dx prostate cancer) to men with screening-diagnosis of prostate cancer at any visit (Dx prostate cancer), subdivided into men who underwent radical retropubic prostatectomy (RRP) and men who did not undergo RRP, Tobago, 1997-2012, among men aged 40-49 years and 50-59 years at first screening. 
at a higher rate than screened men without prostate cancer. This observation occurred despite the history of very limited prostate cancer treatment resources in this population group. This finding suggests that competing causes of death were the primary determinants of mortality in Tobago men of African descent in this older age group. In concurrence with the recommendation of the USPSTF (3), this finding does not support the utility of prostate cancer screening in this older population group, despite high rates of prostate cancer prevalence, incidence and mortality.

Consideration of life expectancy is important in assessing the relevance of these findings to other populations of African descent. Estimates of life expectancy specifically for the island of Tobago ( $94 \%$ African descent (9)) were not available, but could be reasonably estimated to lie between the World Health Organization (WHO) 2012 estimates of male life expectancy of 67 years at birth and 16 years at age 60 years (10) for Trinidad and Tobago (which includes $36.5 \%$ AfroTrinidadians and $37.8 \%$ Indo-Trinidadians (11), who are known to have higher rates of diabetes (12) and stroke (13) than Afro-Trinidadians) and WHO 2012 estimates of male life expectancy of 75 years at birth and 21 years at age 60 years (10) for Barbados males, for whom prostate cancer mortality was similar to that in Tobago men (Fig. 2) (8). Life expectancy at birth in AfricanAmerican males in 2010 was 71.4 years (14). Based on the life expectancy across these populations, we expect our findings of no increased all-cause-mortality related to screening-detected prostate cancer among older AfroCaribbean men to be relevant to African Americans and other populations of African descent with similar life expectancy.

In contrast to the findings among older men, men first screened at age 50-59 years and diagnosed with prostate cancer experienced higher mortality $(p=$ 0.003 ) than non-cases starting after only seven years of follow-up (Fig. 3B), despite the fact that 35\% (44/124) received state-of-the-art treatment. This finding of early divergence of survival curves in younger men is consistent with the Göteborg (Sweden) randomized clinical trial of prostate cancer screening which reported a 14-year follow-up in men recruited at age 50-64 years and found better survival among screened men with divergence beginning around seven years (15). The larger mortality differences between men with and without a diagnosis of prostate cancer among men aged 50-59 years at first screening, compared with the small mortality difference among men aged 60-79 years, may be due to more aggressive prostate cancer among the younger men (16). Or it may simply reflect that competing causes of death were less common among men aged 50-59 years.

A potential weakness of the current study was the relatively low return rate $(65 \%)$ at Visit 3 . The timing of Visit 3 followed a rapid uptake of cell phones and decline of landlines in Tobago, making contact for Visit 3 difficult. The similarity of baseline age, PSA and the proportion of total deaths attributed to prostate cancer between those who returned at Visit 3 and those who did not suggests that there were not large biases with regard to occurrence and severity of prostate cancer between the two groups. However, our study also has notable strengths, including its large population-based sample of men of African ancestry who underwent standardized prostate cancer screening one to three times over eight years and who were followed up for a maximum of 14.8 years after the first screening. To our knowledge, this represents the first prostate cancer screening study with an adequate sample size and length of follow-up to evaluate the potential for overall survival benefit of prostate cancer screening among men of African ancestry.

We conclude that the lack of excess mortality related to screening-detected prostate cancer in men of African ancestry aged $\geq 60$ years supports USPSTF's recommendations against routine screening. In contrast, the significantly higher mortality in men aged 50-59 years with screening-diagnosed prostate cancer and the potential for prostate cancer treatment to improve survival justify the need for further research to assess the benefits and risks of prostate cancer screening and treatment in younger men of African descent. Pending such studies, we conclude that routine prostate cancer screening may be warranted in younger men of African descent.

\section{ACKNOWLEDGEMENTS}

Financial support was provided by grants from the Department of Defense (DAMD17-99-1-9015, Clareann $\mathrm{H}$ Bunker, Principal Investigator) and the National Institutes of Health (R01CA84950, Clareann H Bunker, Principal Investigator; R25CA57703 and R01 AR049747, Joseph M Zmuda, Principal Investigator), United States of America. The Division of Health and Social Services of the Tobago House of Assembly provided in-kind support.

\section{REFERENCES}

1. SEER Fast Stats by Race and Sex Prostate Cancer. Accessed March 26, 2014. Available from: https://seer.cancer.gov/faststats. 
2. Bunker CH, Patrick AL, Konety BR, Dhir R, Brufsky AM, Vivas CA et al. High prevalence of screening-detected prostate cancer among AfroCaribbeans: the Tobago Prostate Cancer Survey. Cancer Epidemiol Biomarkers Prev 2002; 11: 726-9.

3. Moyer VA. Screening for prostate cancer: US Preventive Services Task Force recommendation statement. Ann Intern Med 2012; 157: 120-34.

4. Andriole GL, Crawford ED, Grubb RL $3^{\text {rd }}$, Buys SS, Chia D, Church TR et al. Prostate cancer screening in the randomized Prostate, Lung, Colorectal, and Ovarian Cancer Screening Trial: mortality results after 13 years of follow-up. J Natl Cancer Inst 2012; 104: 125-32.

5. Schroder FH, Hugosson J, Roobol MJ, Tammela TL, Ciatto S, Nelen V et al. Prostate-cancer mortality at 11 years of follow-up. N Engl J Med 2012; 366: 981-90.

6. Boyd-Patrick HA. Health needs assessment: Tobago 1990-94. Scarborough, Tobago, Trinidad and Tobago: Tobago Regional Health Authority, 1997; Table 20.

7. Caribbean Community Secretariat. CARICOM Capacity Development Programme. 2000 round of population and housing census data analysis sub-project. National census report, Trinidad and Tobago. Greater Georgetown, Guyana, 2009.

8. Hennis AJ, Hambleton IR, Wu SY, Skeete DH, Nemesure B, Leske MC. Prostate cancer incidence and mortality in Barbados, West Indies. Prostate Cancer 2011; 2011: 565230.

9. Miljkovic-Gacic I, Ferrell RE, Patrick AL, Kammerer CM, Bunker CH. Estimates of African, European and Native American ancestry in AfroCaribbean men on the island of Tobago. Hum Hered 2005; 60: 129-33.
10. Global Health Observatory Data Repository. Life expectancy: life expectancy by country. (Cited March 29, 2016.) Available from: http:// apps.who.int/gho/data/node.main.688.

11. Central Statistical Office, Ministry of Planning and Development, Trinidad and Tobago. Trinidad \& Tobago 2011 housing and population census. Accessed November 28, 2018. Available from: http://cso.gov.tt/ census/2011-census-data.

12. Miller GJ, Maude GH, Beckles GL. Incidence of hypertension and non-insulin dependent diabetes mellitus and associated risk factors in a rapidly developing Caribbean community: the St James survey, Trinidad. J Epidemiol Community Health 1996; 50: 497-504.

13. Mahabir D, Bickram L, Gulliford MC. Stroke in Trinidad and Tobago: burden of illness and risk factors. Rev Panam Salud Pública 1998; 4: 233-7.

14. Kochanek KD, Arias E, Anderson RN. How did cause of death contribute to racial differences in life expectancy in the United States in 2010? NCHS Data Brief 2013; 125: 1-8.

15. Hugosson J, Carlsson S, Aus G, Bergdahl S, Khatami A, Lodding P et al. Mortality results from the Goteborg randomised population-based prostate-cancer screening trial. Lancet Oncol 2010; 11: 725-32.

16. Daskivich TJ, Fan KH, Koyama T, Albertsen PC, Goodman M, Hamilton AS et al. Effect of age, tumor risk, and comorbidity on competing risks for survival in a US population-based cohort of men with prostate cancer. Ann Intern Med 2013; 158: 709-17. 